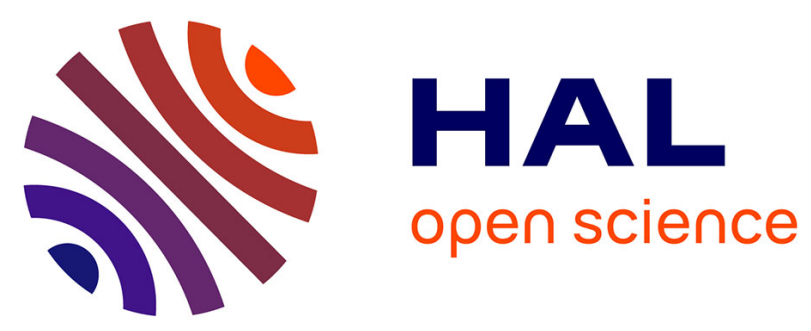

\title{
Differential Sensitivity To Adrenergic Stimulation Underlies The Sexual Dimorphism In The Development Of Diabetes Caused By Irs-2 Deficiency
}

Maria Jose Garcia-Barrado, Maria Carmen Iglesias-Osma, Veronica Moreno-Viedma, Maria Francisca Pastor Mansilla, Silvia Sanz Gonzalez, Jose Carretero, Julio Moratinos, Deborah J. Burks

\section{To cite this version:}

Maria Jose Garcia-Barrado, Maria Carmen Iglesias-Osma, Veronica Moreno-Viedma, Maria Francisca Pastor Mansilla, Silvia Sanz Gonzalez, et al.. Differential Sensitivity To Adrenergic Stimulation Underlies The Sexual Dimorphism In The Development Of Diabetes Caused By Irs-2 Deficiency. Biochemical Pharmacology, 2010, 81 (2), pp.279. 10.1016/j.bcp.2010.10.008 . hal-00649886

\section{HAL Id: hal-00649886 https://hal.science/hal-00649886}

Submitted on 9 Dec 2011

HAL is a multi-disciplinary open access archive for the deposit and dissemination of scientific research documents, whether they are published or not. The documents may come from teaching and research institutions in France or abroad, or from public or private research centers.
L'archive ouverte pluridisciplinaire HAL, est destinée au dépôt et à la diffusion de documents scientifiques de niveau recherche, publiés ou non, émanant des établissements d'enseignement et de recherche français ou étrangers, des laboratoires publics ou privés. 


\section{Accepted Manuscript}

Title: Differential Sensitivity To Adrenergic Stimulation Underlies The Sexual Dimorphism In The Development Of Diabetes Caused By Irs-2 Deficiency

Authors: Maria Jose Garcia-Barrado, Maria Carmen Iglesias-Osma, Veronica Moreno-Viedma, Maria Francisca

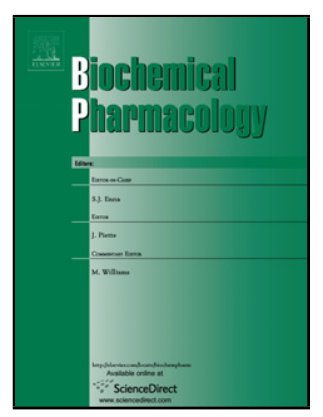

Pastor Mansilla, Silvia Sanz Gonzalez, Jose Carretero, Julio

Moratinos, Deborah J. Burks

PII:

S0006-2952(10)00764-1

DOI: doi:10.1016/j.bcp.2010.10.008

Reference: BCP 10740

To appear in: $\quad B C P$

Received date: $\quad 30-6-2010$

Revised date: $\quad 7-10-2010$

Accepted date: $\quad 11-10-2010$

Please cite this article as: Garcia-Barrado MJ, Iglesias-Osma MC, Moreno-Viedma V, Mansilla MFP, Gonzalez SS, Carretero J, Moratinos J, Burks DJ, Differential Sensitivity To Adrenergic Stimulation Underlies The Sexual Dimorphism In The Development Of Diabetes Caused By Irs-2 Deficiency, Biochemical Pharmacology (2010), doi:10.1016/j.bcp.2010.10.008

This is a PDF file of an unedited manuscript that has been accepted for publication. As a service to our customers we are providing this early version of the manuscript. The manuscript will undergo copyediting, typesetting, and review of the resulting proof before it is published in its final form. Please note that during the production process errors may be discovered which could affect the content, and all legal disclaimers that apply to the journal pertain. 


\title{
DIFFERENTIAL SENSITIVITY TO ADRENERGIC STIMULATION \\ UNDERLIES THE SEXUAL DIMORPHISM IN THE DEVELOPMENT OF DIABETES CAUSED BY IRS-2 DEFICIENCY
}

\begin{abstract}
Abbreviated Title: Female Irs2 ${ }^{-/-}$Mice Display Catecholamine Resistance.
Maria Jose Garcia-Barrado ${ }^{1}$, Maria Carmen Iglesias-Osma ${ }^{1}$, Veronica Moreno-Viedma ${ }^{4}$ Maria Francisca Pastor Mansilla ${ }^{2}$, Silvia Sanz Gonzalez ${ }^{4}$, Jose Carretero ${ }^{3}$, Julio Moratinos ${ }^{1}$, Deborah J. Burks ${ }^{4}$

${ }^{1}$ Department of Physiology and Pharmacology, Faculty of Medicine, University of Salamanca, Salamanca, Spain

${ }^{2}$ University of Valladolid, Valladolid, Spain

${ }^{3}$ Department of Anatomy, Faculty of Medicine, University of Salamanca, Salamanca, Spain

${ }^{4}$ Regenerative Medicine Program, CIBER de Diabetes y Enfermedades Metabólicas

(CIBERDEM), Centro de Investigación Principe Felipe, Valencia, Spain
\end{abstract}

Key Words: Insulin, Diabetes, Adrenergic Receptors, Lipolysis, cAMP

Address Correspondence to:

Deborah Burks, Ph.D.

Centro de Investigacion Principe Felipe

Avenida del Autopista del Saler, 16

46013 Valencia, Spain

TEL: (34) 963289680

FAX: (34) 963289701

Email: dburks@cipf.es

Disclosure Statement: The authors have no conflicts of interest to disclose. 


\section{ABSTRACT}

The diabetic phenotype caused by the deletion of insulin receptor substrate-2 (Irs-2) in mice displays a sexual dimorphism. Whereas the majority of male Irs- $2^{-/-}$mice are overtly diabetic by 12 weeks of age, female Irs- $2^{-/-}$animals develop mild obesity and progress less rapidly to diabetes. Here we investigated $\beta$-cell function and lipolysis as potential explanations for the gender-related differences in this model. Glucose-stimulated insulin secretion was enhanced in islets from male null mice as compared to male WT whereas this response in female Irs- $2^{-/-}$islets was identical to that of female controls. The ability of $\alpha_{2^{-}}$ adrenoceptor $\left(\alpha_{2}\right.$-AR) agonists to inhibit insulin secretion was attenuated in male Irs2 null mice. Consistent with this, the expression of the $\alpha_{2 \mathrm{~A}}-\mathrm{AR}$ was reduced in male Irs- $2^{-/-}$islets. The response of male Irs- $2^{-/-}$islets to forskolin was enhanced, owing to increased production of cAMP. Basal lipolysis was increased in male Irs $-2^{-/-}$but decreased in female Irs $-2^{-/-}$mice, concordant with the observation that adipose tissue is sparse in males whereas female Irs2 null mice are mildly obese. Adipocytes from both male and female Irs- $2^{-/-}$were resistant to the anti-lipolytic effects of insulin but female Irs- $2^{-/-}$fat cells were additionally resistant to the catabolic effects of beta-adrenergic agonists. This catecholamine resistance was associated with impaired generation of cAMP. Consequently, targets of cAMP-dependent protein kinase (PKA) which mediate lipolysis were not phosphorylated in adipose tissue of female Irs- $2^{-/-}$ mice. Our findings suggest that IRS-2 deficiency in mice alters the expression and/or sensitivity of components of adrenergic signaling. 


\section{$-3-$}

\section{INTRODUCTION}

The presence of a sexual dimorphism is observed in almost all mouse models of diabetes, including those generated by altering insulin signaling, with males displaying a predominance of the diabetic phenotype [1-4]. However, with the non-obese diabetes (NOD) mouse model of type 1 diabetes, there is a strong tendency for females to develop diabetes, even though both genders present lymphocytic infiltration of the islets $[5,6]$. The specific factors which mediate sexual dimorphisms remain largely unexplained in these experimental models of diabetes. Thus, the molecular mechanisms underlying the gender-specific differences which modulate the development and progression of diabetes may provide important clues for the design of anti-diabetic drugs or therapies in human patients.

Various lines of evidence suggest that catecholamines and adrenergic receptors are involved in the etiology and pathogenesis of type 2 diabetes mellitus [7, 8], which is characterized by an insufficient secretion of insulin to compensate for resistance to insulin action in peripheral tissues [9]. Indeed, the plasma concentrations of catecholamines are higher in diabetic than in healthy subjects $[10,11]$ and glucose intolerance is frequently observed in patients with endocrine disorders such as pheochromocytoma $([12,13]$. The antisecretagogue effect of catecholamines is mediated primarily by the stimulation of alpha 2adrenoceptors $\left(\alpha_{2}\right.$-AR) in pancreatic beta cells, suggesting that increased sympathetic innervation or a reinforced $\alpha_{2}$-adrenergic response in pancreatic islets may account for the impaired secretory response to glucose observed in certain forms of type 2 diabetes $[14,15]$. Adrenaline and other $\alpha_{2}$-adrenoceptor agonists inhibit insulin secretion by a number of mechanisms coupled to the Gi/Go signaling system, including inhibition of adenylate cyclase (AC) and cAMP production [16], activation of $\mathrm{K}^{+}$channels [17, 18], and inhibition of L-type voltage-dependent $\mathrm{CA}^{+2}$ channels [19]. Generation of mice deficient in $\alpha_{2}$-AR subtypes has demonstrated that insulin secretion is modulated principally by the $\alpha-2 \mathrm{~A}$ AR; the absence of 
inhibitory pancreatic beta-cell $\alpha_{2 \mathrm{~A}^{-}} \mathrm{AR}$ function causes hyperinsulinaemia, reduced blood glucose levels and improved glucose tolerance in knockout mice [20]. Conversely, overexpression of $\alpha_{2 A^{-}}$AR specifically in beta cells causes hyperglycemia in response to $\alpha_{2^{-}}$ AR agonists due to reduced insulin secretion [21]. A recent study has demonstrated that a single-nucleotide polymorphism in the human $A D R A 2 A$ gene is associated with overexpression of $\alpha_{2 \mathrm{~A}}-\mathrm{AR}$, reduced insulin secretion, and increased risk for type 2 diabetes [22]. Consistent with these findings, a genome-wide association (GWA) project has recently linked the $A D R A 2 A$ locus with beta-cell dysfunction in humans with Type 2 diabetes [23].

Given that obesity is closely associated with the development of diabetes, the effects of catecholamines on the metabolic parameters of white and brown adipose tissue represent another target for intervention in this disease ([24]. The three $\beta$-adrenergic receptor ( $\beta$-AR) subtypes ( $\beta$-AR1, $\beta$-AR2, and B-AR3) are coupled to Gos for increasing intracellular cAMP levels [25]. In white adipose tissue, lipolysis is regulated by activation of adenylyl cyclase and cAMP-dependent protein kinase (PKA) which stimulates lipase, the enzyme that catalyzes the breakdown of triacylglycerol into glycerol and free fatty acids (FFA) [26]. By contrast, activation of $\alpha_{2}$ - adrenoceptors inhibits lipolysis [27]. In most models of obesity, the $\beta$-AR system is dysfunctional [28] leading to impairments of lipolysis and thermogenesis. However, whereas activation of the B-AR subtypes can stimulate lipolysis, the involvement of each subtype varies according to fat location, species, gender, age, and degree of obesity [29]. Interestingly, selective agonists for the $\beta$-AR3, the subtype expressed predominantly in adipocytes [30], prevent or reverse obesity and accompanying insulin resistance in animal models. Whether these agonists represent a viable therapeutic option for human obesity is much debated. Nevertheless, the physiological changes in adrenoceptor function associated with obesity in rodent models have yielded beneficial insights into B-AR signaling and adipocyte physiology. 


\section{- 5 -}

Members of the insulin receptor substrate (IRS) protein family mediate the physiological effects of insulin and IGF-I [31]. Deletion of IRS-2 produces diabetes in mice owing to peripheral insulin resistance and a reduction in pancreatic B-cell mass [32]. However, this diabetic phenotype displays a sexual dimorphism; male Irs- $2^{-/-}$mice often die of diabetic complications by 12 weeks of age but female Irs- $2^{-/-}$develop a milder form of diabetes and many live up to 6 months [33, 34]. Additionally, female Irs-2 deficient mice display hyperleptinemia and develop moderate obesity $[35,36]$, in contrast to male Irs- $2^{-/-}$ which are often leaner than control mice. In the present study, we used a pharmacological approach to 1) characterize in greater detail the sexual dimorphism of the Irs- $2^{-/-}$model with respect to beta cell function and lipolysis and 2) to explore the contributions of adrenergic signaling to the diabetic phenotype of Irs-2 deficient animals. 


\section{MATERIAL AND METHODS}

2.1. Animal Experimentation. The generation and genotyping of mice deficient for Irs- $2^{-/-}$ have been described previously [3]. The mice used in the present study were maintained on a C57B16 background and were allowed free access to food (irradiated chow, Harlan 20/14) and water during controlled light-dark cycles of 12 hours. All mice were studied at 8-10 weeks of age and any which were overtly diabetic (>220 fed glucose mg/dl or 120 fasted glucose $\mathrm{mg} / \mathrm{dl}$ ) were excluded in order to examine the consequences of Irs- $2^{-/-}$deficiency under conditions which minimize the complications of diabetic metabolism. For routine measurements of fasting glucose and insulin, mice were fasted for 16 hours and a small quantity of tail blood was extracted for immediate analysis by a glucometer (Bayer Elite model, Bayer Healthcare, Barcelona, Spain). Circulating insulin was measured by a mouse ultra-sensitive ELISA (Mercodia, Uppsala, Sweden, http://www.mercodia.se). When fed values for insulin and glucose were assessed by these same methods, tail blood was collected consistently between 10 and 11 AM. All experimental procedures were approved by the institutional committee for animal experimentation.

2.2. Adipocyte isolation and lipolysis assay. The details of this experimental procedure have been described previously [37]. Briefly, intra-abdominal white adipose tissue (WAT) of perirenal and epididymal origin was removed from fed animals. Adipose tissue was digested for 35 to $45 \mathrm{~min}$ at $37{ }^{\circ} \mathrm{C}$ under shaking with $1.5 \mathrm{mg} / \mathrm{ml}$ collagenase A (Roche Diagnostics, Mannheim, Germany) in Krebs-Ringer containing $15 \mathrm{mM}$ sodium bicarbonate, $6 \mathrm{mM}$ glucose, $10 \mathrm{mM}$ HEPES, and bovine serum albumin $(35 \mathrm{mg} / \mathrm{ml})$ adjusted to $\mathrm{pH} 7.4$ (KRBA buffer). Isolated fat cells were filtered and washed three times in KRBA buffer to eliminate collagenase. The packed cells were diluted in around 10-fold their volume of KRBA, and $500 \mu \mathrm{l}$ of cell suspension was distributed into plastic incubation vials. Therefore, after 90-min 
incubation under gentle shaking at $37{ }^{\circ} \mathrm{C}$ with the indicated final concentration of tested drugs, the glycerol released into the medium was assayed and lipolytic activity was expressed as $\mu$ moles of glycerol released/100 mg of cellular lipid/90 min. Changes in glycerol release are expressed as percentages of mean control. A one-way analysis of variance (ANOVA) and the Newman-Keuls test were used for statistical analysis. Results were considered significant if $\mathrm{P}<0.05$.

2.3. Islet isolation and measurement of insulin secretion/content. Islets were isolated by collagenase digestion (Inmunogenetics, Madrid, Spain) of the pancreas of fed female and male WT and IRS-2 $2^{--}$mice, followed by manual selection using a dissecting microscope [38]. They were free of visible exocrine contamination. The medium used for islet isolation was a bicarbonate-buffered solution (HCO3 medium) containing $120 \mathrm{mM} \mathrm{NaCl}, 4.8 \mathrm{mM} \mathrm{KCl}, 2.5$ $\mathrm{mM} \mathrm{CaCl}{ }_{2}, 1.2 \mathrm{mM} \mathrm{MgCl} 2,5 \mathrm{mM}$ HEPES and $24 \mathrm{mM} \mathrm{NaHCO}_{3}$. It was equilibrated with $\mathrm{O}_{2^{-}}$ $\mathrm{CO}_{2}$ (94:6) to maintain a $\mathrm{pH}$ of 7.4 and was supplemented with $1 \mathrm{mg} \mathrm{ml}^{-1} \mathrm{BSA}$ and $10 \mathrm{mM}$ glucose. After isolation, the islets were pre-incubated for 60 min in HCOS medium containing $15 \mathrm{mM}$ glucose before being distributed into batches of three. Each batch of islets was then incubated for $60 \mathrm{~min}$ in $1 \mathrm{ml}$ at $37^{\circ} \mathrm{C}$ of medium containing glucose and test substances. A portion of the medium was withdrawn at the end of the incubation to measure the insulin concentration. Additionally, the islets were recovered following the incubation and total insulin content was determined after extraction in acid-ethanol [39]. Insulin was measured by a double-antibody RIA (Schering Laboratories, Madrid, Spain). Calculations and statistics were performed with the Instat software (GraphPad, San Diego, CA, USA). Results are provided as mean \pm S.E.M. Statistical significance was assessed by the Student's t-test or the 
one-way analysis of variance (ANOVA) corrected by the Newman-Keuls test. Results were considered significant if $\mathrm{P}<0.05$.

2.4. Immunohistochemistry and quantification of beta cell area. Pancreata were removed at the time of sacrifice and fixed for 16 hours in Bouin's solution (Sigma, Steinheim, Germany, http://www.sigmaaldrich.com). Subsequently, pancreatic tissue was embedded in paraffin and sections of $5 \mu$ icrons were prepared. Following re-hydration and permeabilization with $1 \%$ Triton $\mathrm{X}-100$, sections were incubated with anti-insulin (Sigma, http://www.sigmaaldrich.com) and anti-glucagon (Sigma, http://www.sigmaaldrich.com) antibodies overnight at $4^{\circ} \mathrm{C}$. Detection was performed with rhodamine and fluorescein conjugated secondary antibodies (Jackson Immunoresearch, USA, $\underline{w w w . j a c k s o n i m m u n o . c o m})$. For quantification of $\beta$-cell area, sections were viewed using a Zeiss Axiovert S100 TV microscope at a magnification of 10x. The islet cross-sectional area and total pancreatic area were measured using Openlab Image analysis software (Improvision Imaging). At least 3 sections, separated by $200 \mu \mathrm{m}$ were measured per animal. For quantification of the number of islets per area, only islets with more than 5 cells were scored.

2.5. Western Blotting. Abdominal fat depots were collected and frozen immediately in liquid nitrogen. Tissue was lysed in RIPA buffer $(\mathrm{NaCl} 150 \mathrm{mM}$, Tris 50mM, EDTA 1mM, EGTA $1 \mathrm{mM}$, SDS $0.1 \%$, Sodium deoxycholate $0.5 \%, \mathrm{NP}-401 \%, \mathrm{Na}_{3} \mathrm{VO}_{4} 1 \mathrm{mM}, \mathrm{NaF} 1 \mathrm{mM}$ ) by polytron and homogenates were clarified by centrifugation at $12,000 \mathrm{x} \mathrm{g}$ for $10 \mathrm{~min}$. Protein determination was by the Biorad assay. $50 \mu \mathrm{g}$ of total protein was separated by SDS-PAGE. Gels were transferred to Immun-Blot ${ }^{\mathrm{TM}}$ PVDF Membrane (Bio-Rad Laboratories, Hercules CA, www.bio-rad.com) and incubated with one of the following antibodies: rabbit antiphospho PKA substrate (Cell Signaling, http://www.cellsignal.com), anti-perilipin A/B 
(Sigma, http://www.sigmaaldrich.com), rabbit anti-alpha2A adrenergic receptor (Acris Antibodies, Hiddenhausen, Germany, www.acris-antibodies.com), or anti-hormone sensitive lipase (Santa Cruz, http://www.scbt.com/), or rabbit anti-beta tubulin (Sigma, http://www.sigmaaldrich.com). Westerns were developed by ECL (Pierce, Thermo Scientific, Rockford IL, http://www.piercenet.com/).

2.6. Measurement of Intracellular cAMP Content. Islets were isolated as described above in batches of 100 size-matched islets. Subsequently, the medium was changed to adjust glucose concentrations to $3 \mathrm{mM}$ or $15 \mathrm{mM}$, with or without forskolin, in $\mathrm{KRBH}$ containing $1 \mathrm{mM}$ isobutylmethylxanthine (IBMX) which prevents cAMP degradation by inhibiting cyclic nucleotide phosphodiesterases. Following a 30 min incubation at $37^{\circ} \mathrm{C}$, islets were collected by centrifugation and the pellet was frozen immediately in liquid N2. Adipocytes were isolated and incubated with pharmacological agents as described above. Intracellular cAMP levels were assessed using the AlphaScreen cAMP kit (Perkin-Elmer, Massachusetts, USA http://las.perkinelmer.com). Statistical significance was evaluated by the Student's t-test. Results are expressed as mean \pm S.E.M.

\section{RESULTS}

\subsection{Metabolic differences between male and female IRS2-deficient mice cannot be explained by beta cell number or insulin content.}

To explore the physiological basis of the sexual dimorphism in the Irs2 knockout model, we first measured fed blood glucose and insulin levels in mice of 8-10 weeks of age. Fed plasma glucose values in both male and female Irs $2^{-/-}$mice were higher than in their WT controls (Fig. 1A), although the differences were less pronounced in female mice. Mice which were overtly diabetic (>220 fed glucose $\mathrm{mg} / \mathrm{dl}$ or 120 fasted glucose $\mathrm{mg} / \mathrm{dl}$ ) were excluded from study in order to examine the contributions of Irs- $2^{-/-}$deficiency under conditions which 
minimize the complications of diabetic metabolism. Both male and female Irs- $2^{-/-}$displayed higher fed insulin values in comparison to their WT controls, although this was statistically significant only in males (Fig. 1B). Consistent with previous reports, the female Irs $2^{-/-}$mice in our study weighed more than their WT controls (Irs $2^{--}: 19.3$ grams \pm 2.40 , WT: $15.9 \mathrm{~g} \pm 2.23$; $\mathrm{p}<0.05, \mathrm{n}=10$ mice of each genotype) whereas no differences were observed between the body weights of male transgenic and control mice (Irs2 $2^{--}: 20.6$ grams \pm 2.19 , WT: $20.3 \mathrm{~g} \pm$ 2.05; $\mathrm{n}=10$ mice of each genotype). To determine whether the metabolic differences between male and female IRS2-deficient mice could be explained by differences in the beta cell population, histological analysis was performed. Beta cell mass was reduced in both males and females, although to a slightly lesser extent in females (male Irs $-2^{-1}: 40.2 \% v s$. female Irs$2^{-1}: 28.5 \%$ ) (Fig. 1C). When total pancreas insulin content was evaluated (Figure 1D), it was reduced similarly in male and female Irs- $2^{-/-}$mice (males: WT $1,719 \pm 145$ vs. Irs- $2^{-/}: 1.287$ $\pm 44 \mathrm{mIU} /$ islet; females: WT $1,202 \pm 105$ vs. Irs- $\left.2^{-/} 928 \pm 76 \mathrm{mIU} / \mathrm{islet}\right)$. The integrity of the insulin secretory response to glucose was evaluated by measuring glucose-stimulated insulin release from isolated islets. In response to various concentrations of glucose, islets from Irs- $2^{-}$ ${ }^{1-}$ males secreted more insulin than WT controls whereas the response of female Irs- $2^{-/}$was identical to WT control females (Fig. 1E, F). Thus, the rapid progression of diabetes in males Irs2 null mice could not be explained by gender differences in beta cell area and insulin content but was associated with defective insulin secretion.

\subsection{Secretion of insulin by male Irs- $2^{-/}$islets displays altered sensitivity to adrenergic agonists and forskolin}

Since it is well established that the sympathetic nervous system can modulate insulin secretion, we tested the effect of various types of pharmacological agonists on insulin release under conditions where glucose was maintained at $15 \mathrm{mM}$. The muscarinic agonist carbachol increased insulin secretion equivalently in islets from all genotypes (Fig. 2A). Brimonidine 
(UK 14,304), an agonist for $\alpha_{2}$ adrenoceptors, at a dose of $1 \mu \mathrm{M}$ reduced insulin secretion as

expected in control islets (figure 2A). However, inhibition of insulin secretion by this $\alpha_{2}$ agonist in male Irs $2^{-/-}$was significantly less efficient than its effect on WT islets. We reasoned that this decreased sensitivity to brimonidine might reflect down-regulation of $\alpha_{2}$-AR or modifications of cAMP signalling components at the post-receptor level. To test these possibilities, we performed Western blot analysis and, interestingly, observed that expression of $\alpha_{2 \mathrm{~A}}$-AR was reduced in islets of male Irs- $2^{-/-}$mice (Figure $2 \mathrm{~B}$ ).

Based on these observations, we tested the response of Irs- $2^{-/-}$islets to forskolin, a direct activator of adenylate cyclase which is known to promote insulin secretion by increasing intracellular cAMP. The response of male Irs- $2^{-/-}$islets to forskolin was enhanced in comparison to WT controls, whereas female Irs- $2^{-/-}$islets displayed a slight decrease in the response to this cAMP agonist (Figure 2C). To further explore this altered response, we measured cAMP production in islets stimulated with either glucose or forskolin. The generation of cAMP in islets of male Irs- $2^{-/-}$displayed enhanced sensitivity to both glucose and forskolin (Figure 2D), consistent with the insulin secretion results. In contrast, islets of female IRS2-deficient mice produced less cAMP in response to forskolin than female controls. These results suggest that the increased sensitivity of cAMP-generation in islets of male $\operatorname{Irs} 2^{-/-}$males, combined with reduced expression of $\alpha_{2 \mathrm{~A}} \mathrm{AR}$, contributes to the dysregulated insulin secretion and hyperinsulinemia observed in these animals.

\subsection{Basal and Insulin-inhibited Lipolysis in Males vs. Females}

As mentioned previously, female Irs- $2^{-/-}$develop moderate obesity whereas body weight of males is comparable to their WT controls, at least during the pre-diabetic phase. Although Irs $2^{-/}$is known to have an important role in hypothalamic regulation of appetite and obesity $[36,40]$, we considered the possibility that adipose metabolism might also contribute 
to differences between male and female Irs- $2^{-/-}$. Therefore, we measured glycerol release in adipocytes isolated from male and female mice of both genotypes. Basal lipolysis in male Irs$2^{-/-}$was increased by $21 \%$ whereas it was reduced in females Irs- $2^{-/-}$by $19 \%$, in comparison to their respective WT controls (Figure 3A). When we tested the effects of insulin on lipolysis in isolated adipocytes, this hormone suppressed glycerol release effectively at both concentrations $\left(10^{-8}\right.$ and $\left.10^{-7} \mathrm{M}\right)$ in WT animals (Figure 3B, C). In contrast, lipolysis was not inhibited significantly by insulin in male (Figure 3B) or female Irs- $2^{-/-}$adipocytes (Figure 3C), suggesting that these animals are resistant to insulin action. Previous studies have demonstrated that IRS2-deficiency causes peripheral insulin resistance, particularly in liver [41].

\subsection{Adipocytes of female $\operatorname{Irs}-2^{-/-}$mice display resistance to $\beta$-adrenergic-mediated}

\section{lipolysis}

One of the major counter-regulatory mechanisms for controlling lipolysis is the adrenergic system. Catecholamines modulate lipolysis through lipolytic $\beta$-adrenoceptor and anti-lipolytic $\alpha_{2}$-adrenoceptor [24]. Given the altered basal lipolysis in male and female Irs- $2^{-/-}$ , we examined the effects of adrenergic stimulation on isolated adipocytes. Isoproterenol, a classic B-agonist, increased lipolysis in adipocytes from male WT and Irs- $2^{-/-}$in a dosedependent manner (Figure 4A). In sharp contrast, adipocytes isolated from female Irs- $2^{-/-}$ displayed a blunted response to isoproterenol, particularly at high concentrations $\left(10^{-7}\right.$ and $10^{-}$ ${ }^{6} \mathrm{M}$ ) of this agonist. (Figure 4B). This defective response to $\beta$-adrenergic agonists in female Irs- $2^{-/-}$fat cells may reflect an inability to elevate intracellular cAMP, owing either to impaired cAMP generation or an increase to its degradation. We next tested the effects of the $\alpha_{2}$-adrenergic agonist brimonidine on isoproterenol-stimulated lipolysis which would be expected to inhibit given that $\alpha_{2 \mathrm{~A}}-\mathrm{AR}$ decreases adenylate cyclase activity. At the highest dose 
(10-6 M) isoproterenol, brimonidine attenuated significantly glycerol release in male and female WT adipocytes (Figure 4C and D). However, in male Irs- $2^{-/-}$fat cells, brimonidine had no effect on isoproterenol-induced lipolysis, consistent with the reduced sensitivity to brimonidine observed in islets of male null mice. The inhibitory effects of brimonidine on lipolysis were also not significant in female Irs- $2^{-/-}$adipocytes but this is most likely explained by the apparent resistance of these cells to isoproterenol.

\subsection{Female Irs- $2^{-/-}$adipocytes are less sensitive to forskolin}

To investigate whether the resistance to $\beta$-adrenergic agonists in female Irs- $2^{-/-}$ adipocytes reflects alterations at the receptor or post-receptor level, the effects of forskolin on lipolysis were tested. In male Irs- $2^{-/-}$fat cells, forskolin $\left(10^{-5} M\right)$ increased basal lipolysis to a greater extent than in WT ( $40 \%$ of control, $p<0.001$, Figure 5A). However, forskolin was less effective at stimulating lipolysis in adipocytes of female transgenics as compared to female WT controls (20\% less glycerol was released when compared with WT, $p<0.001$, figure 5B).

Given the dampened response to both $\beta$-adrenergic agonists and forskolin in female Irs- $2^{-/-}$adipocytes, we next evaluated cAMP generation in response to these agents. Consistent with the lipolysis data, generation of cAMP in adipocytes of male Irs- $2^{-/-}$mice displayed increased sensitivity to forskolin. In contrast, the ability of isoproterenol as well as forskolin to promote cAMP accumulation was attenuated in adipocytes of female Irs- $2^{-/-}$as compared with female controls. Thus, these results reveal a potential explanation for the failure of forskolin and isoproteronol to stimulate lipolysis in adipocytes derived from female IRS2deficient mice.

\section{6. cAMP signalling and expression of hormone sensitive lipase are reduced in adipose}

\section{$\underline{\text { tissue of female Irs- } 2^{-/-} \text {mice }}$}


Perilipin A (Plin) is a major lipid droplet protein that regulates basal and PKAstimulated lipolysis [42, 43]. Plin is required for the translocation of hormone-sensitive lipase (HSL) from the cytosol to lipid droplets upon stimulation [44]. When catecholamines bind to their receptors and initiate signals that increase cAMP, PKA phosphorylates Plin A which then promotes the translocation of HSL to facilitate maximal lipolysis. Thus, to determine whether the reduced ability to elevate cAMP agents in female Irs $-2^{-/}$adipocytes has consequences for downstream targets of the lipolytic pathway, we examined the phosphorylation of Plin A/B in adipose tissue lysates by Western blotting with an antibody specific for substrates of PKA. Although total expression levels were similar between Irs-2 males and WT males as well as between Irs-2 females and WT females, basal PKA-mediated phosphorylation of Plin A/B was notably reduced in the adipose tissue of Irs-2 deficient females (Fig. 6A). These results suggest that reduced sensitivity to cAMP-elevating agents impairs the PKA pathway in adipose tissue of female Irs2 null mice. Additionally, the expression of HSL was notably reduced in adipocytes of female Irs- $2^{-/-}$mice (Fig. 6B). Collectively, these alterations may explain the reduced lipolysis and increased body weight of female Irs2-deficient mice.

\section{DISCUSSION}

The development of diabetes in Irs- $2^{--}$null mice has been well-characterized and is attributed to beta cell insufficiency paired with severe insulin resistance [32]. However, the sexual dimorphism associated with this diabetic phenotype is poorly understood. In our study, circulating insulin levels were not significantly different between WT and Irs $2^{-/-}$females. However, male Irs- $2^{--}$animals were hyperinsulinemic when compared with their WT controls. Consistent with this, glucose-stimulated insulin secretion was enhanced in islets from male Irs- $2^{-/}$whereas no difference was observed between female WT and Irs $-2^{-/-}$ 
animals. The metabolic differences between male and female IRS2-deficient mice could not

be explained on the basis of differential defects in the $\beta$-cell population and/or insulin content. $\beta$-cell mass was reduced in Irs2 null mice of both genders, though to a slightly lesser extent in females and insulin content was diminished to a similar extent in both male and female transgenic mice.

This compensatory hyperinsulinemia could derive from an adaptive response of the autonomic nervous system to the pathology of pre-diabetes since differences were observed when we analysed the inhibitory effect of the adrenergic agents on insulin secretion. Brimonidine, an $\alpha_{2}$-AR agonist, inhibited insulin secretion less efficiently in male Irs- $2^{-/-}$mice than in their WT controls. Additionally, the expression of this $\alpha_{2 \mathrm{~A}}-\mathrm{AR}$ was down-regulated in male but not in female IRS2-deficient islets, consistent with the reduced response to the inhibitory effects of $\alpha_{2}$-AR on insulin release. Since $\alpha_{2 \mathrm{~A}}$-AR appears to be the main receptor in beta cells and mediates the inhibition of adenylate cyclase, reduced expression of this receptor would be expected to favor increased intracellular levels of cAMP [45, 46]. Therefore, dysregulation of cAMP could explain the enhanced insulin secretory response to both glucose and forskolin observed in islets of male Irs- $2^{-/}$mice. Indeed, the cAMPdependent guanine nucleotide exchange factor EPAC potentiates exocytosis by interacting with $\mathrm{K}^{+} \mathrm{ATP}$ and $\mathrm{Ca}^{+2}$ voltage channels and by promoting granule fusion events. [47]. Chronic, elevated insulin levels have been reported in $\alpha_{2}-\mathrm{AR}^{-/-}$mice and animals deprived of noradrenergic tonic inhibition $[20,48]$. Recent studies in humans have suggested that the $\alpha_{2^{-}}$ AR may also play an important role in development of diabetes. A single-nucleotide polymorphism in the human $A D R A 2 A$ gene has been correlated with overexpression of $\alpha_{2 \mathrm{~A}^{-}}$ AR, reduced insulin secretion, and increased risk for type 2 diabetes [22]. Consistent with these findings, a GWA study has recently linked the ADRA2A locus with beta-cell dysfunction in humans with Type 2 diabetes [23]. 
Basal lipolysis was significantly increased in male Irs- $2^{-/-}$adipocytes whereas it was markedly reduced in female Irs- $2^{-/-}$in comparison to their WT controls. When we tested the anti-lipolytic effect of insulin on isolated fat cells, glycerol release was suppressed in WT samples but insulin had no significant inhibitory effect on lipolysis in adipocytes of male or female Irs- $2^{-/-}$mice. This results suggest that IRS2 may play a role in regulating insulin sensitivity in adipose tissue. Thus, our lipolysis data confirm the presence of insulin resistance and hyperinsulinemia in male Irs- $2^{-/-}$mice. In female Irs- $2^{-/-}$animals, not only was the basal rate of lipolysis reduced in comparison to WT females but the expected lipolytic response to either isoproterenol or forskolin was clearly attenuated; even at a concentration of $10^{-6} \mathrm{M}$, the glycerol release evoked by isoproterenol was reduced by approximately $50 \%$ in adipocytes of Irs- $2^{-/-}$females. Consistent with this altered lipolytic response, cAMP generation in response to isoprenaline and forskolin was reduced in adipocytes of Irs- $2^{-/-}$females as compared with female controls, suggesting that post-receptor defects may contribute to the catecholamine resistance in these animals. The enhanced lipolytic response to forskolin in adipocytes of male Irs- $2^{-/-}$adipocytes was associated with increased production of cAMP. Given that we detected reduced expression of $\alpha_{2 \mathrm{~A}}$-AR in islets of male Irs- $2^{-/-}$, it is possible that the absence of an $\alpha_{2}$ AR inhibitory effect also increases cAMP levels in male Irs- $2^{-/-}$adipocytes, thereby predisposing them to an increased basal rate of lipolysis.

The observation that PKA-mediated phosphorylation of perilipin is significantly reduced in adipose tissue is consistent with the defective accumulation of cAMP in fat cells of female Irs- $2^{-{ }^{-}}$mice. Moreover, female Irs- $2^{-{ }^{-}}$adipocytes display another defect not present in their male counterparts which is a significant reduction in the expression of HSL. In Irs $1^{-/-}$ mice, which are lean and resistant to the effects of high-fat diet, HSL expression in adipocytes is enhanced more than 4-fold [49,50], suggesting that IRS1 and IRS2 may differentially regulate expression of lipolytic enzymes. These data provide a molecular explanation for the 
development of moderate obesity in female Irs2-deficient animals; since phosphorylation of perilipin by PKA is required for the translocation of HSL to lipid droplets, the observed defects in adipocytes of female Irs- $2^{-/-}$would be expected to impair lipolysis and facilitate fat storage. Interestingly, diminished expression of HSL has been observed in patients with obesity and Type 2 diabetes [51,52]. Studies in humans have also demonstrated that the expression of $B-A R 2$ and the regulatory IIß-subunit of PKA are reduced in adipocytes of female patients with polycystic ovary disease (PCOS), a common endocrine disorder characterized by obesity and insulin resistance [53,54]. These defects are associated with catecholamine resistance and decreased lipolytic activity in vivo which promotes obesity in PCOS patients. In addition to the metabolic abnormalities characterized by beta cell failure and insulin resistance, Irs- $2^{--}$females are infertile as IRS-2 signals are required for ovarian function and proper regulation of the reproductive axis [36, 55]. Thus, the presence of catecholamine resistance and perturbed cAMP signaling in adipose tissue of Irs- $2^{-/-}$females suggest that these mice may represent a valid model for unravelling the molecular mechanisms underlying the pathology of PCOS.

In summary, the sexual dimorphism described for the diabetic phenotype of Irs- $2^{-1-}$ mice can be explained, at least partially, by differential defects in pancreatic islets and adipose tissue. In female Irs- $2^{-/-}$mice at 8-10 weeks of age, reduced basal lipolysis and catecholamine resistance in adipocytes are paired with a normal secretory response to glucose in pancreatic beta cells. Conversely, in male IRS2-deficient mice of the same age, basal lipolysis is enhanced as adipocytes are resistant to both insulin and to the inhibitory effects of $\alpha_{2}$ AR agonists, a situation that requires increased secretion of insulin and favours a more rapid progression of diabetes. These metabolic differences between male and female Irs- $2^{-/-}$mice must also reflect some influence of sex steroid hormones. In addition to its role in the physiology of reproduction, estrogen modulates metabolic parameters. For example, estrogen 
plays an essential role in adaption to pregnancy by enhancing insulin byosinthesis and glucose-stimulated insulin secretion [56]. However, as both gonadotropins and steroid hormones are reduced in the infertile Irs $2^{-/}$females $[36,55]$, it is unlikely that the influence of estrogen and progesterone on gene expression has a major role in delaying the progression of diabetes in females versus males of this experimental model. The metabolic alterations which underlie this sexual dimorphism appear to be associated with differential defects in the cAMP system, including reduced expression of $\alpha_{2}$ AR in $\beta$-cells of male Irs- $2^{-/-}$and impaired generation of cAMP in adipose tissue of female Irs- $2^{-/-}$mice.

ACKNOWLEGEMENTS: This work was supported by Instituto de Salud Carlos III-FIS grant PI03/0652, Fundación Mutua Madrileña, CIBER de Diabetes y Enfermedades Metabólicas del Instituto de Salud ISCIII, EMER007 (ISCIII), Ministerio de Ciencia y Innovación SAF2008-00011, Programa de Juan de la Cierva del MICINN (Silvia Sanz), and the Regenerative Medicine Program of the Valencian Community.

\section{REFERENCES}

[1] Kadowaki T. Insights into insulin resistance and type 2 diabetes from knockout mouse models. J Clin Invest 2000;106:459-465.

[2] Oriel RC, Wiley CD, Dewey MJ, Vrana PB. Adaptive genetic variation, stress and glucose regulation. Dis Model Mech 2008;1:255-263.

[3] Withers DJ, Gutierrez JS, Towery H, Burks DJ, Ren JM, Previs S, et al. Disruption of IRS-2 causes type 2 diabetes in mice. Nature 1998;391:900-904.

[4] Wells JC. Sexual dimorphism of body composition. Best Pract Res Clin Endocrinol Metab 2007;21:415-430.

[5] Amrani A, Durant S, Throsby M, Coulaud J, Dardenne M, Homo-Delarche F. Glucose homeostasis in the nonobese diabetic mouse at the prediabetic stage. Endocrinology 1998;139:1115-1124.

[6] Kikutani H, Makino S. The murine autoimmune diabetes model: NOD and related strains. Adv Immunol 1992;51:285-322.

[7] Ahren B. Evidence that autonomic mechanisms contribute to the adaptive increase in insulin secretion during dexamethasone-induced insulin resistance in humans. Diabetologia 2008;51:1018-1024.

[8] Ahren B. Autonomic regulation of islet hormone secretion--implications for health and disease. Diabetologia 2000;43:393-410. 
[9] Redmon JB, Towle HC, Robertson RP. Regulation of human insulin gene transcription by glucose, epinephrine, and somatostatin. Diabetes 1994;43:546-551.

[10] Robertson RP, Halter JB, Porte D, Jr. A role for alpha-adrenergic receptors in abnormal insulin secretion in diabetes mellitus. J Clin Invest 1976;57:791-795.

[11] Christensen NJ. Catecholamines and diabetes mellitus. Diabetologia 1979;16:211-224.

[12] Isles CG, Johnson JK. Phaeochromocytoma and diabetes mellitus: further evidence that alpha 2 receptors inhibit insulin release in man. Clin Endocrinol (Oxf) 1983;18:37-41.

[13] Stenstrom G, Sjostrom L, Smith U. Diabetes mellitus in phaeochromocytoma. Fasting blood glucose levels before and after surgery in 60 patients with phaeochromocytoma. Acta Endocrinol (Copenh) 1984;106:511-515.

[14] Ostenson CG, Cattaneo AG, Doxey JC, Efendic S. Alpha-adrenoceptors and insulin release from pancreatic islets of normal and diabetic rats. Am $\mathbf{J}$ Physiol 1989;257:E439-443.

[15] Guillot E, Coste A, Angel I. Alpha 2-adrenoceptors and the regulation of glucose, insulin and amylin levels in diabetic rats. Life Sci 1995;57:2081-2090.

[16] Nakaki T, Nakadate T, Ishii K, Kato R. Postsynaptic alpha-2 adrenergic receptors in isolated rat islets of Langerhans: inhibition of insulin release and cyclic 3':5'-adenosine monophosphate accumulation. J Pharmacol Exp Ther 1981;216:607-612.

[17] Drews G, Debuyser A, Nenquin M, Henquin JC. Galanin and epinephrine act on distinct receptors to inhibit insulin release by the same mechanisms including an increase in K+ permeability of the B-cell membrane. Endocrinology 1990;126:16461653.

[18] Rorsman P, Bokvist K, Ammala C, Arkhammar P, Berggren PO, Larsson O, et al. Activation by adrenaline of a low-conductance $\mathrm{G}$ protein-dependent $\mathrm{K}+$ channel in mouse pancreatic B cells. Nature 1991;349:77-79.

[19] Nilsson T, Arkhammar P, Rorsman P, Berggren PO. Inhibition of glucose-stimulated insulin release by alpha 2-adrenoceptor activation is parallelled by both a repolarization and a reduction cytoplasmic free $\mathrm{Ca} 2+$ concentration. J Biol Chem 1988;263:1855-1860.

[20] Savontaus E, Fagerholm V, Rahkonen O, Scheinin M. Reduced blood glucose levels, increased insulin levels and improved glucose tolerance in alpha2A-adrenoceptor knockout mice. Eur J Pharmacol 2008;578:359-364.

[21] Devedjian JC, Pujol A, Cayla C, George M, Casellas A, Paris H, Bosch F. Transgenic mice overexpressing alpha2A-adrenoceptors in pancreatic beta-cells show altered regulation of glucose homeostasis. Diabetologia 2000;43:899-906.

[22] Rosengren AH, Jokubka R, Tojjar D, Granhall C, Hansson O, Li DQ, et al. Overexpression of alpha2A-adrenergic receptors contributes to type 2 diabetes. Science 2010;327:217-220.

[23] Dupuis J, Langenberg C, Prokopenko I, Saxena R, Soranzo N, Jackson AU, et al. New genetic loci implicated in fasting glucose homeostasis and their impact on type 2 diabetes risk. Nat Genet 2010;42:105-116.

[24] Langin D. Adipose tissue lipolysis as a metabolic pathway to define pharmacological strategies against obesity and the metabolic syndrome. Pharmacol Res 2006;53:482491.

[25] Alexander SP, Mathie A, Peters JA. Guide to Receptors and Channels(GRAC), 3rd edition. Br J Pharmacol 2008;153:S1-209.

[26] Fu L, Isobe K, Zeng Q, Suzukawa K, Takekoshi K, Kawakami Y. The effects of beta(3)-adrenoceptor agonist CL-316,243 on adiponectin, adiponectin receptors and 
tumor necrosis factor-alpha expressions in adipose tissues of obese diabetic KKAy mice. Eur J Pharmacol 2008;584:202-206.

[27] Fain JN, Garcija-Sainz JA. Adrenergic regulation of adipocyte metabolism. J Lipid Res 1983;24:945-966.

[28] Butler AA, Cone RD. Knockout models resulting in the development of obesity. Trends Genet 2001;17:S50-54.

[29] Arner P. Human fat cell lipolysis: biochemistry, regulation and clinical role. Best Pract Res Clin Endocrinol Metab 2005;19:471-482.

[30] Emorine LJ, Marullo S, Briend-Sutren MM, Patey G, Tate K, Delavier-Klutchko C, Strosberg AD. Molecular characterization of the human beta 3-adrenergic receptor. Science 1989;245:1118-1121.

[31] Kitamura T, Kahn CR, Accili D. Insulin receptor knockout mice. Annu Rev Physiol 2003;65:313-332.

[32] Burks DJ, White MF. IRS proteins and beta-cell function. Diabetes 2001;50:S140145.

[33] Kubota N, Tobe K, Terauchi Y, Eto K, Yamauchi T, Suzuki R, et al. Disruption of insulin receptor substrate 2 causes type 2 diabetes because of liver insulin resistance and lack of compensatory beta-cell hyperplasia. Diabetes 2000;49:1880-1889.

[34] Hashimoto H, Arai T, Ohnishi Y, Eto T, Ito M, Hioki K, et al. Phenotypes of IRS-2 deficient mice produced by reproductive technology are stable. Exp Anim 2007;56:149-154.

[35] Tobe K, Suzuki R, Aoyama M, Yamauchi T, Kamon J, Kubota N, et al. Increased expression of the sterol regulatory element-binding protein-1 gene in insulin receptor substrate-2(-/-) mouse liver. J Biol Chem 2001;276:38337-38340.

[36] Burks DJ, Font de Mora J, Schubert M, Withers DJ, Myers MG, Towery HH, et al. IRS-2 pathways integrate female reproduction and energy homeostasis. Nature 2000;407:377-382.

[37] Iglesias-Osma MC, Garcia-Barrado MJ, Visentin V, Pastor-Mansilla MF, Bour S, Prevot D, Valet P, Moratinos J, Carpene C. Benzylamine exhibits insulin-like effects on glucose disposal, glucose transport, and fat cell lipolysis in rabbits and diabetic mice. J Pharmacol Exp Ther 2004;309:1020-1028.

[38] Garcia-Barrado MJ, Ravier MA, Rolland JF, Gilon P, Nenquin M, Henquin JC. Inhibition of protein synthesis sequentially impairs distinct steps of stimulus-secretion coupling in pancreatic beta cells. Endocrinology 2001;142:299-307.

[39] Detimary P, Jonas JC, Henquin JC. Possible links between glucose-induced changes in the energy state of pancreatic B cells and insulin release. Unmasking by decreasing a stable pool of adenine nucleotides in mouse islets. J Clin Invest 1995;96:1738-1745.

[40] Kubota N, Terauchi Y, Tobe K, Yano W, Suzuki R, Ueki K, et al. Insulin receptor substrate 2 plays a crucial role in beta cells and the hypothalamus. J Clin Invest 2004;114:917-927.

[41] Valverde AM, Burks DJ, Fabregat I, Fisher TL, Carretero J, White MF, Benito M. Molecular mechanisms of insulin resistance in IRS-2-deficient hepatocytes. Diabetes 2003;52:2239-2248.

[42] Ducharme NA, Bickel PE. Lipid droplets in lipogenesis and lipolysis. Endocrinology 2008;149:942-949.

[43] Granneman JG. Delivery of DNA into adipocytes within adipose tissue. Methods Mol Biol 2008;423:191-195.

[44] Shen WJ, Patel S, Miyoshi H, Greenberg AS, Kraemer FB. Functional interaction of hormone-sensitive lipase and perilipin in lipolysis. J Lipid Res 2009. 
[45] Grill V, Cerasi E. Activation by glucose of adenyl cyclase in pancreatic islets of the rat. FEBS Lett 1973;33:311-314.

[46] Delmeire D, Flamez D, Hinke SA, Cali JJ, Pipeleers D, Schuit F. Type VIII adenylyl cyclase in rat beta cells: coincidence signal detector/generator for glucose and GLP-1. Diabetologia 2003;46:1383-1393.

[47] Tengholm A, Gylfe E. Oscillatory control of insulin secretion. Mol Cell Endocrinol 2009;297:58-72.

[48] Ste Marie L, Palmiter RD. Norepinephrine and epinephrine-deficient mice are hyperinsulinemic and have lower blood glucose. Endocrinology 2003;144:4427-4432.

[49] Tsuji Y, Kaburagi Y, Terauchi Y, Satoh S, Kubota N, Tamemoto H, et al. Subcellular localization of insulin receptor substrate family proteins associated with phosphatidylinositol 3-kinase activity and alterations in lipolysis in primary mouse adipocytes from IRS-1 null mice. Diabetes 2001;50:1455-1463.

[50] Selman C, Lingard S, Choudhury AI, Batterham RL, Claret M, Clements M, et al. Evidence for lifespan extension and delayed age-related biomarkers in insulin receptor substrate 1 null mice. FASEB J 2008;22:807-818.

[51] Large V, Arner P. Regulation of lipolysis in humans. Pathophysiological modulation in obesity, diabetes, and hyperlipidaemia. Diabetes Metab 1998;24:409-418.

[52] Watt MJ, Carey AL, Wolsk-Petersen E, Kraemer FB, Pedersen BK, Febbraio MA. Hormone-sensitive lipase is reduced in the adipose tissue of patients with type 2 diabetes mellitus: influence of IL-6 infusion. Diabetologia 2005;48:105-112.

[53] Faulds G, Ryden M, Ek I, Wahrenberg H, Arner P. Mechanisms behind lipolytic catecholamine resistance of subcutaneous fat cells in the polycystic ovarian syndrome. J Clin Endocrinol Metab 2003;88:2269-2273.

[54] Ek I, Arner P, Bergqvist A, Carlstrom K, Wahrenberg H. Impaired adipocyte lipolysis in nonobese women with the polycystic ovary syndrome: a possible link to insulin resistance?. J Clin Endocrinol Metab 1997;82:1147-1153.

[55] Neganova I, Al-Qassab H, Heffron H, Selman C, Choudhury AI, Lingard SJ, et al. Role of central nervous system and ovarian insulin receptor substrate 2 signaling in female reproductive function in the mouse. Biol Reprod 2007;76:1045-1053.

[56] Nadal A, Alonso-Magdalena P, Soriano S, Ropero AB, Quesada I. The role of oestrogens in the adaptation of islets to insulin resistance. J Physiol 2009;587:50315037.

\section{FIGURE LEGENDS}

Figure 1. Characterization of beta cell function in male and female mice.

(A) Fed blood glucose levels were measured in animals of 8-10 weeks of age. $n=14$ male

WT, 14 male Irs- $2^{-/-}, 16$ females WT and 18 females Irs- $2^{-{ }^{-}} . * * * \mathrm{p}<0.001, * * \mathrm{p}<0.01 .(\mathbf{B})$

Circulating insulin levels from fed animals were measured by ELISA. $\mathrm{n}=14$ male WT, 14

male Irs- $2^{-/-}, 16$ female WT and 18 female Irs- $2^{-/_{-}} * * * p<0.01(\mathbf{C})$ Quantification of beta cell

area. Animals were sacrificed at 8-10 weeks of age. Pancreas sections were stained with anti- 
insulin antibodies and beta cell area was determined using serial sections. n= 4 male WT, 4 male Irs- $2^{-{ }^{-}}, 3$ female WT and 4 female Irs $-2^{-{ }^{-}}$.**p $<0.01$. (D) Total insulin content was determined from isolated islets by radioimmunoassay and plotted as $\mu$ units of total insulin content per islet. For the experiment, 25-30 batches of three islets from the experimental groups were matched carefully by size. Data represent the average \pm SEM of 6 WT and 6 Irs$2^{-/}$animals. $* * p<0.01$. (E) Glucose-stimulated insulin release was measured in the presence of 3,15 and $30 \mathrm{mM}$ of glucose in islets isolated from male or $(\mathrm{F})$ female animals (8-10 weeks of age). Insulin levels were determined by radioimmunoassay and plotted as $\mu$ units of insulin per islet $/ \mathrm{h} . \mathrm{n}=9$ males of each genotype and $\mathrm{n}=10$ females of each genotype. $* * * \mathrm{p}<0.001, * *$ $p<0.01$. Note: The results of the female Irs $-2^{-/-}$were identical to female WT control and thus, the lines of the graph in $\mathrm{F}$ are superimposed.

Figure 2. Analysis of insulin release in male and female mice. (A) The effects of carbachol $(100 \mu \mathrm{M})$ and brimonidine $(\mathrm{UK} 14,304,1 \mu \mathrm{M})$ on insulin release were tested in islets of male and female mice (8-10 weeks of age). Pancreatic islets were incubated for $60 \mathrm{~min}$ in $1 \mathrm{ml}$ of bicarbonate-buffered medium (HCOS medium supplemented with $1 \mathrm{mg} / \mathrm{ml}$ of BSA and $5 \mathrm{mM}$ HEPES, see Methods) containing the indicated drug concentrations and $15 \mathrm{mM}$ glucose. Values are expressed as percentages of mean control $(100 \%, 15 \mathrm{mM}$ glucose of each animal) \pm SEM of 10-15 batches of three islets from 8-10 animals. ${ }^{*} p<0.05$. (B) Expression of the $\alpha-2 \mathrm{~A}^{-}$ AR in isolated islets of male mice was analysed by Western blotting. Anti-beta tubulin was used to confirm equal loading of samples. Islets were pooled from three animals of each genotype. (C) The effects of forskolin $(\mathrm{FK}, 1 \mu \mathrm{M})$ on insulin release were tested in isolated islets as indicated in A. Values are expressed as percentages of mean control (100\%, glucose $15 \mathrm{mM}) \pm$ SEM of $10-15$ batches of three islets from 8-10 animals. $* * p<0.05$. (D) Islets were isolated as described and incubated in HCOS medium (see Methods) containing $3 \mathrm{mM}$ 
glucose. Subsequently, batches of 100 size-matched islets from each genotype were selected. Islets were then stimulated with either forskolin or $15 \mathrm{mM}$ glucose for 10 minutes as described in $\mathbf{C}$. The stimulation with forskolin was performed in triplicate and samples were lysed to measure intracellular cAMP. ${ }^{* *} p<0.01,{ }^{*} p<0.05$.

Figure 3. Basal glycerol release in isolated adipocytes and inhibition by insulin. (A) Following isolation of adipocytes from abdominal fat, basal lipolytic activity in wild-type vs. Irs2- $-^{-/}$mice (8-10 weeks of age) was measured. Values are expressed as means $\pm \mathrm{SE}$ obtained from the analysis of the following groups of mice: male WT $(n=29)$, male Irs- $2^{-/-}(n=28)$, female WT $(n=46)$ and female Irs- $2^{-/}(n=41)$. Data are expressed relative to basal lipolysis, which was set as 100\% in WT animals of each gender (absolute values for basal glycerol released in WT mice were $0.34 \pm 0.05$ and $0.42 \pm 0.02 \mu \mathrm{mol} / 100 \mathrm{mg}$ lipid/90 min for male and female, respectively). $* * p<0.01$ and $* p<0.05$. (B and $\mathbf{C}$ ) Anti-lipolytic effect of insulin on basal glycerol release. Increasing concentrations of insulin $\left(10^{-8}\right.$ and $\left.10^{-7} \mathrm{M}\right)$ were added to the incubation media and the percentage of inhibition of glycerol release from adipocytes of male (B) and female (C) mice was measured. $*^{* *} p<0.01$ and $* p<0.05$.

\section{Figure 4. Analysis of adrenergic-regulated lipolysis in adipocytes.}

(A and B) Analysis of isoproterenol-induced glycerol release. Fat cells from WT and Irs2 $2^{-1-}$ male (A) and female (B) mice of 8-10 weeks of age were incubated 90 min with increasing concentrations $\left(10^{-9}-10^{-6} \mathrm{M}\right)$ of the $\beta$-adrenergic agonist, isoproterenol (Iso). Basal lipolysis was considered as $100 \%$ in WT animals of each gender. Data are presented as means $\pm \mathrm{SE}$ (see Fig. 3A for absolute values in WT mice). ${ }^{*} p<0.05$ and ${ }^{* *} p<0.01 . \mathrm{n}=6$ mice of each experimental group. (C and D) Effects of the $\alpha 2$-adrenergic agonist brimonidine (UK 14,304) on isoproterenol-induced glycerol release from mouse adipocytes. Values are expressed as 
mean \pm SE relative to the percentage of WT basal values (100\% of WT of each gender). *p $<0.05$ and ${ }^{* *} \mathrm{p}<0.01 . \mathrm{n}=4$ mice of each experimental group.

\section{Figure 5. cAMP-mediated glycerol liberation in isolated mouse adipocytes.}

(A and B) Effects of $10 \mu \mathrm{M}$ forskolin (FK) on basal lipolysis. Basal lipolysis was established as $100 \%$ in WT animals of each gender. ${ }^{* * *} p<0.001 . \mathrm{n}=4$ animals of each experimental group. (C) Triplicates of isolated adipocytes from each experimental group were stimulated with the indicated concentrations of either isoproterenol or forskolin for 10 min. Samples were then lysed and assayed for intracellular cAMP. $n=6$ mice of each experimental group. $* P<0.05$ and $* * P<0.01$.

Figure 6. Analysis of cAMP-dependent signaling in adipose tissue. (A) Western analysis of perilipin $\mathrm{A} / \mathrm{B}$ expression and phosphorylation. Visceral adipose tissue was removed and protein lysates were prepared from four animals of each genotype. $500 \mu \mathrm{g}$ of total protein were immunoprecipitated (from pools of two animals of each experimental group) using antiperilipin A/B and these immunocomplexes were then separated by SDS-PAGE. The membrane was first incubated with anti-phospho PKA substrate to detect phosphorylated perilipinA/B. Subsequently, the blot was stripped and re-probed to reveal total levels of perilipin A/B. Blots were scanned and phospho-perilipin A (approximately $62 \mathrm{kDa}$ ) was quantified by densitometry. Total perilipin A/B was used to normalize the levels of phosphoperilipin $\mathrm{A} / \mathrm{B}$. A representative blot from two independent experiments is presented. Total $\mathrm{n}=$ 8 animals of each group. (B) Western analysis of hormone-sensitive lipase expression in adipose tissue. $50 \mu \mathrm{g}$ of the adipose tissue lysates prepared in $\mathbf{A}$ were probed with anti-HSL antibodies. Anti-beta actin was used to confirm equal protein loads. Molecular weight is indicated at the left of each membrane. 
$-25-$

1

2

3

4

5

6

7

8

10

11

12

13

14

15

16

17

18

19

20

21

22

23

24

25

26

27

28

29

30

31

32

33

34

35

36

37

38

39

40

41

42

43

44

45

46

47

48

49

50

51

52

53

54

55

56

57

58

59

60

61

62

63

64 
A

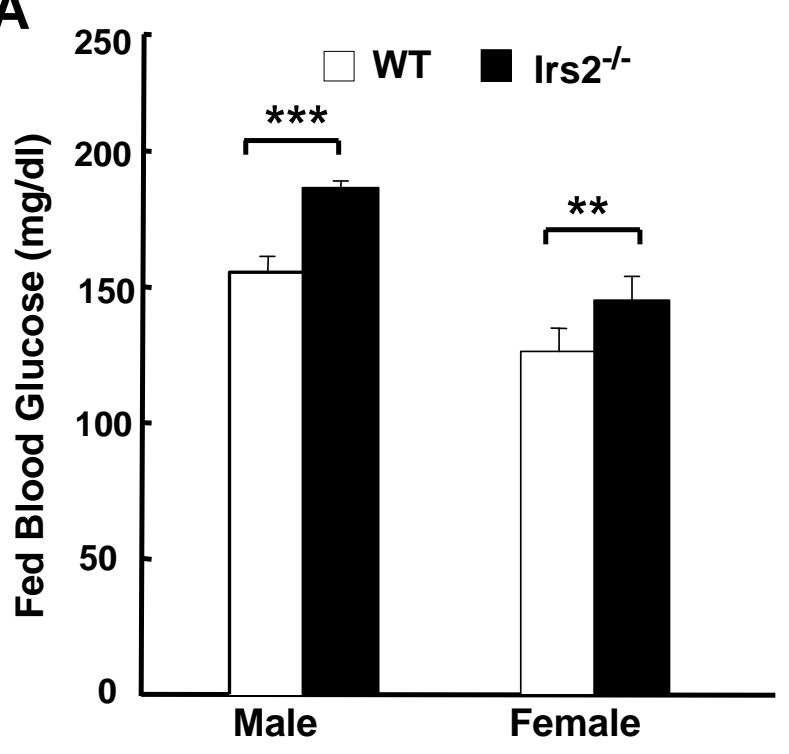

B

Garcia-Barrado Figure 1

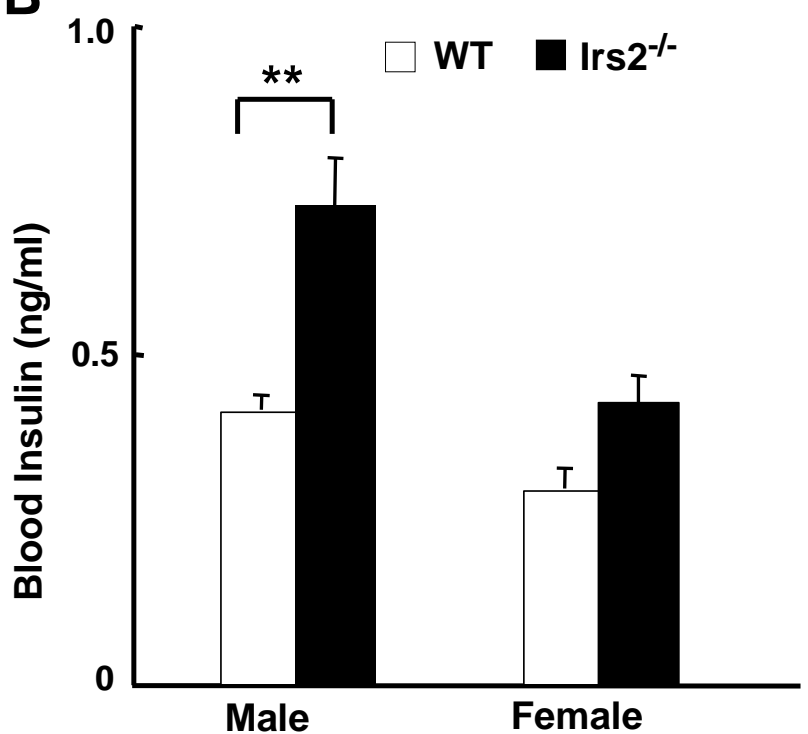

D

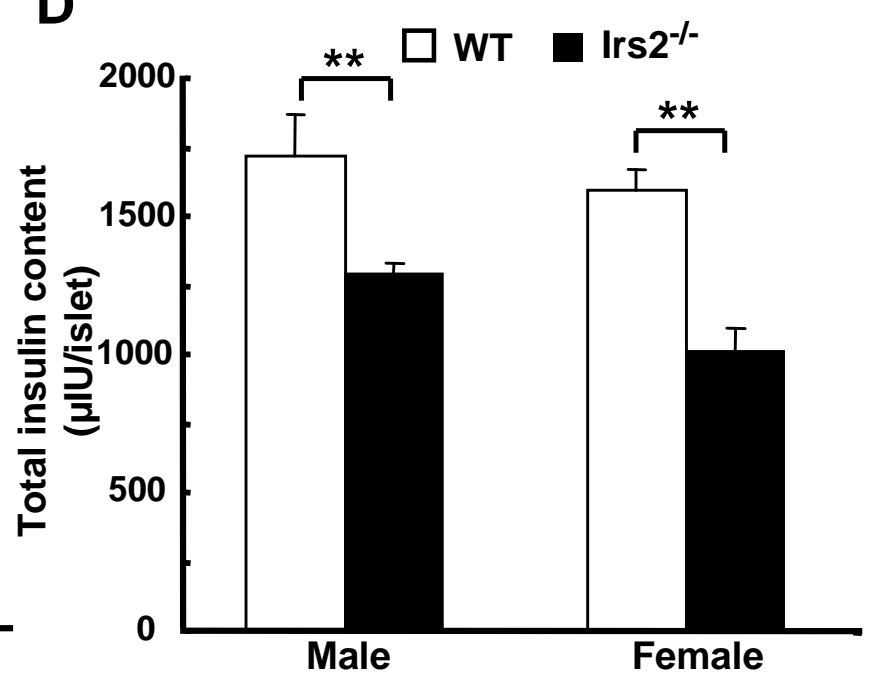

$\mathbf{F}$

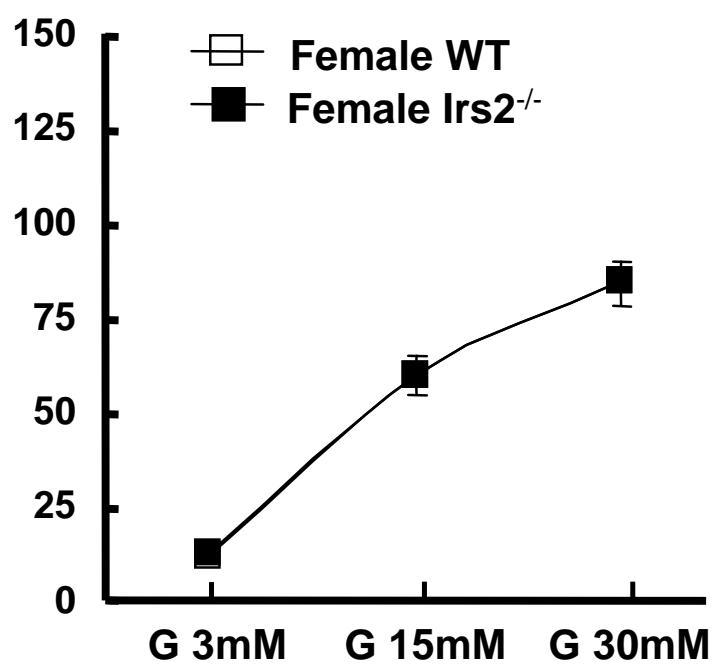



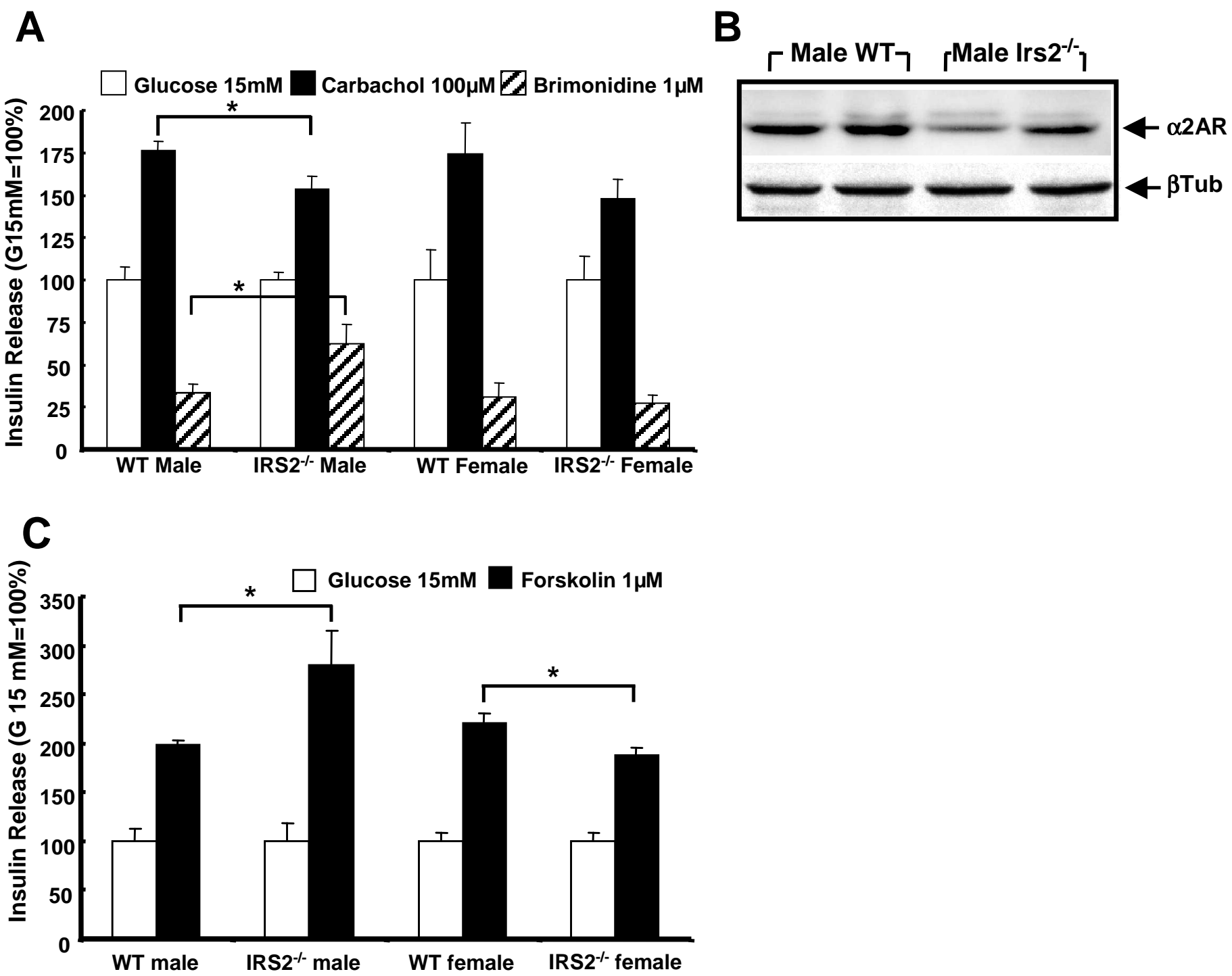

D

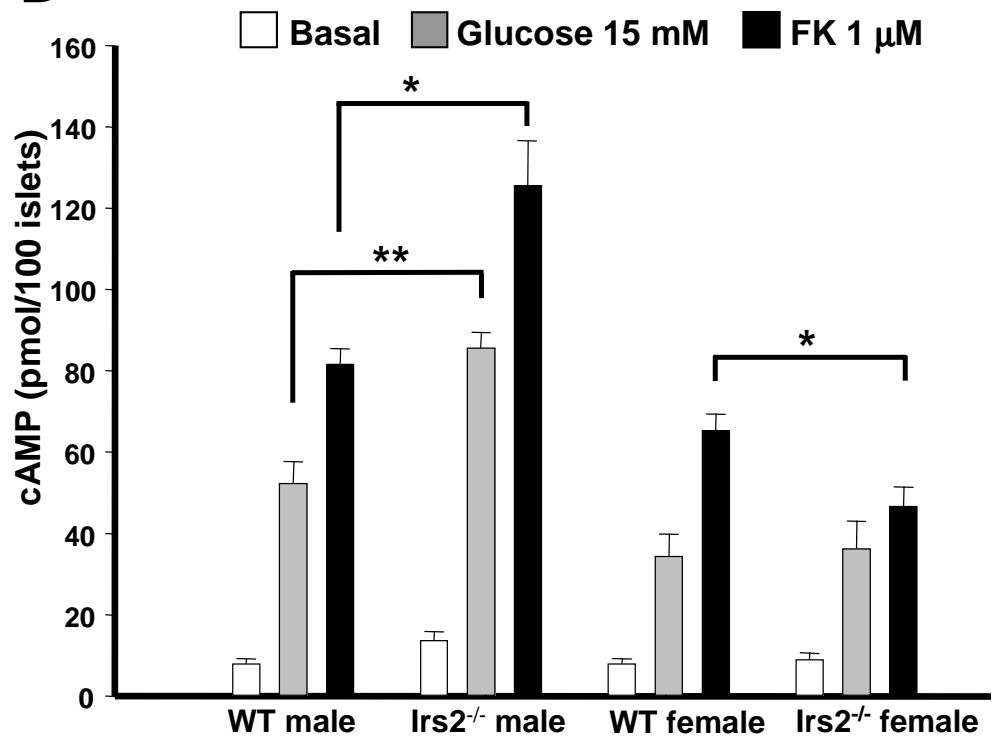


Garcia-Barrado Figure 3
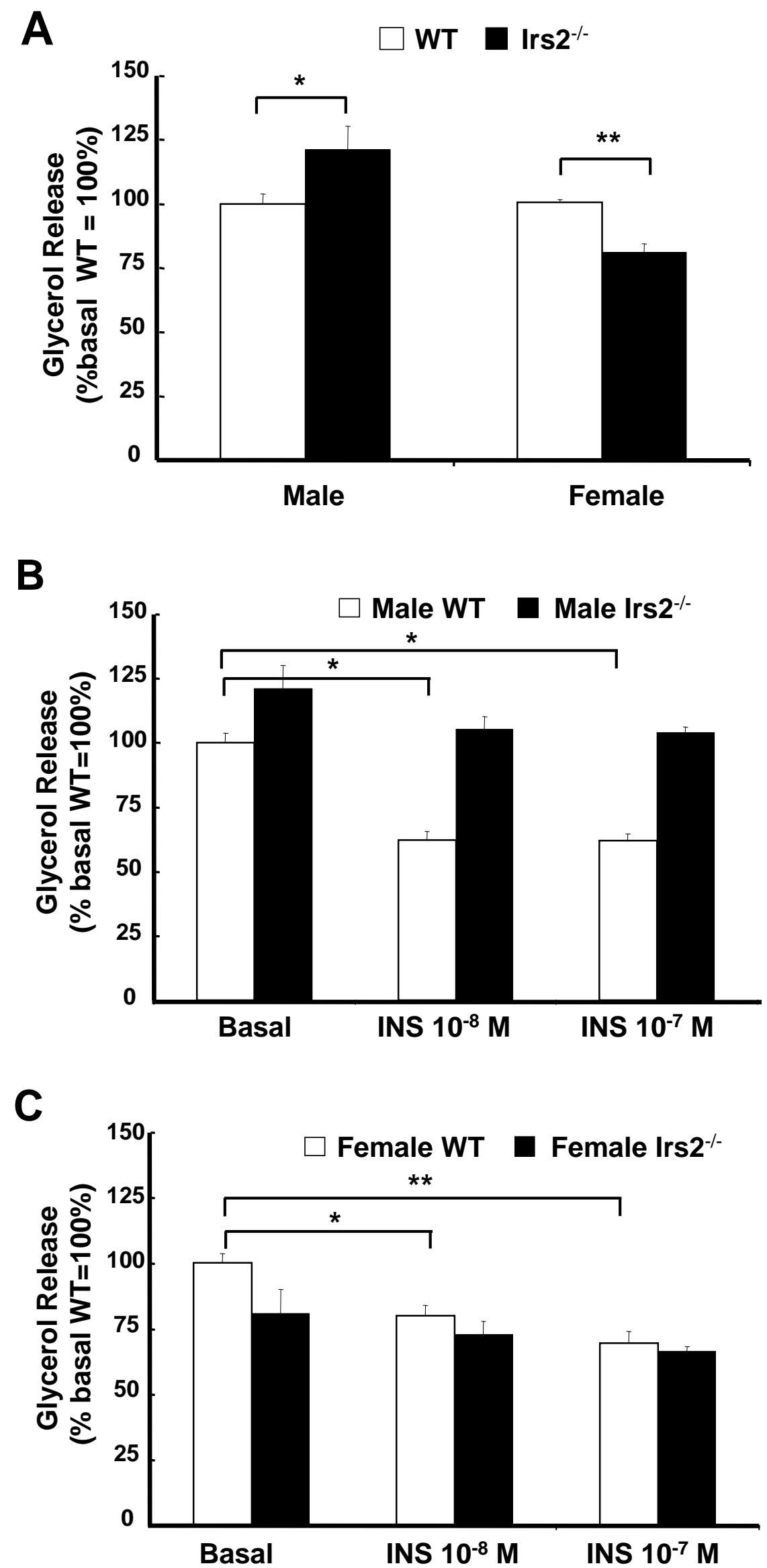


\section{Garcia-Barrado Figure 4}

A

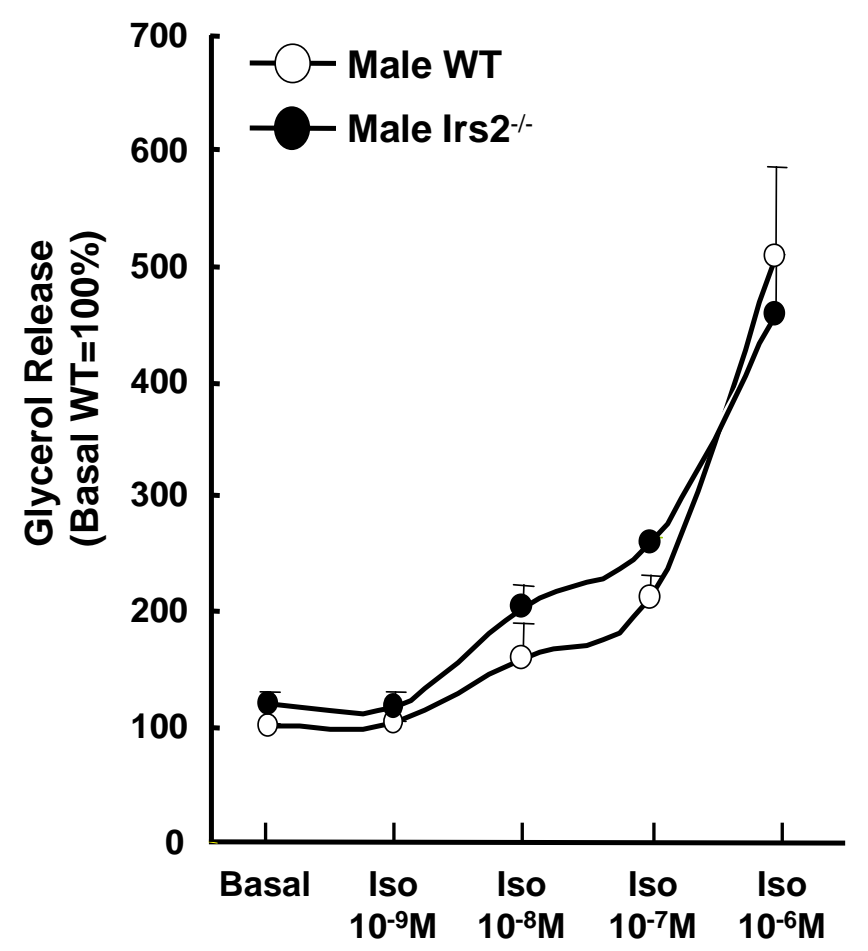

C

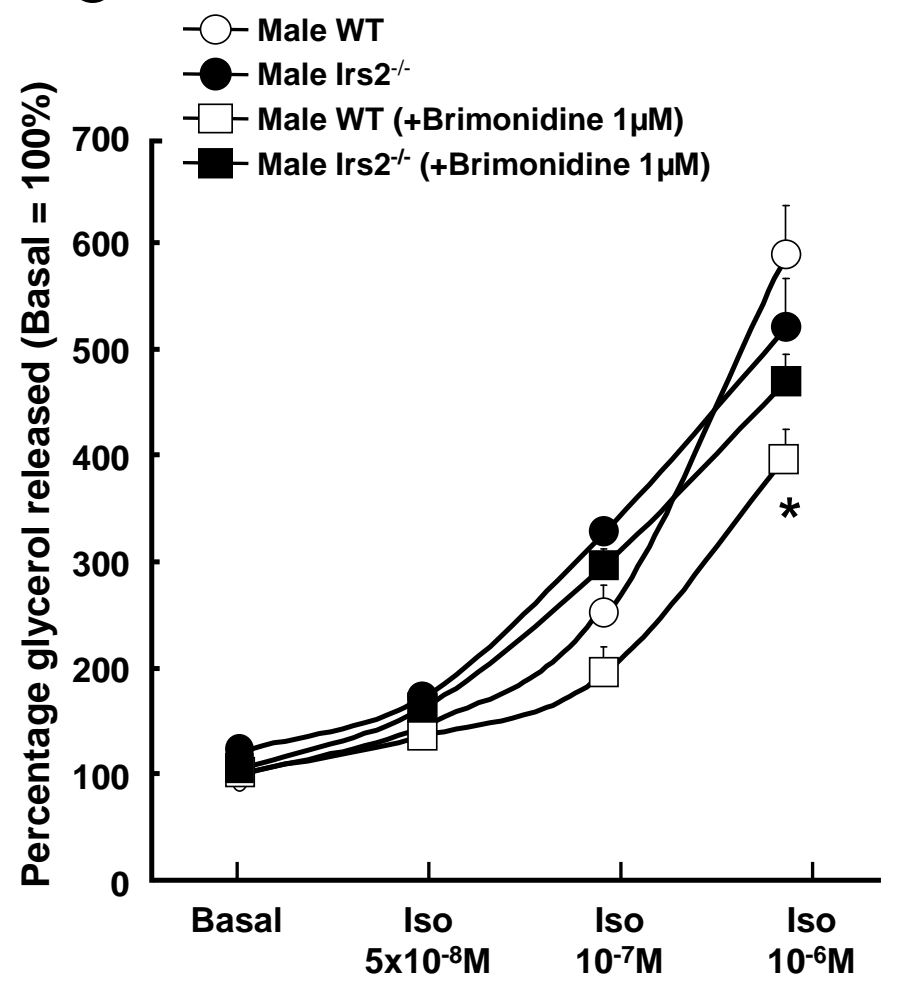

B
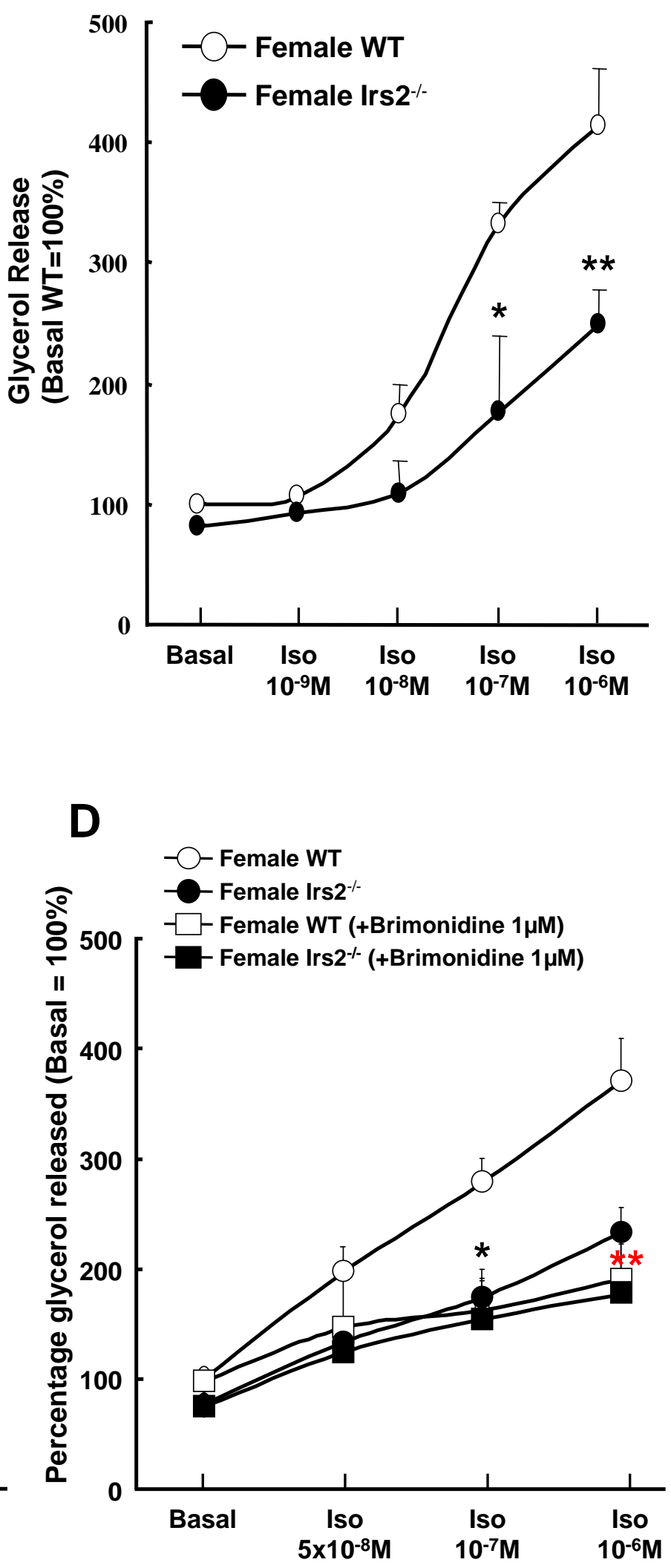
Garcia-Barrado Figure 5

A

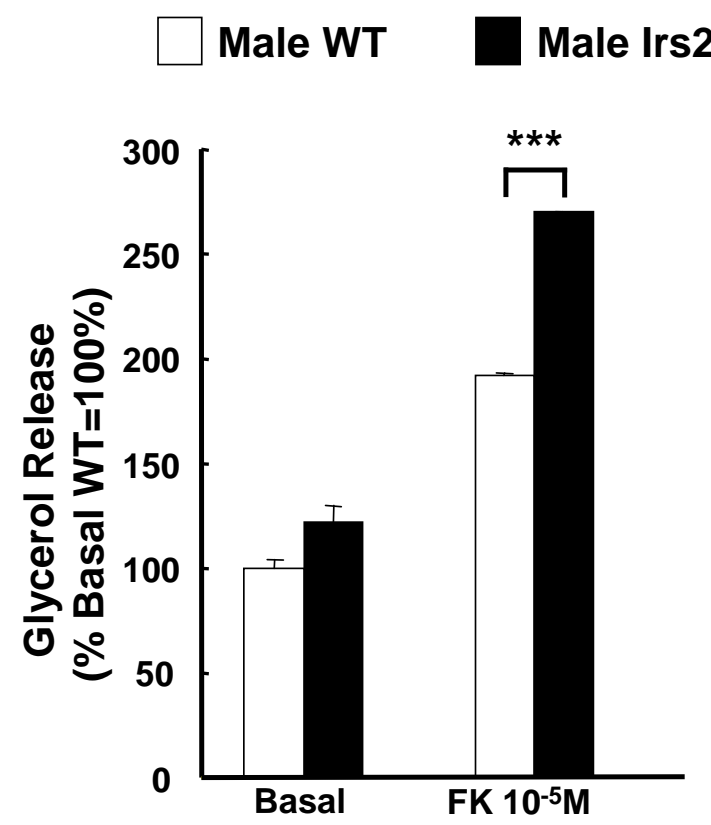

B

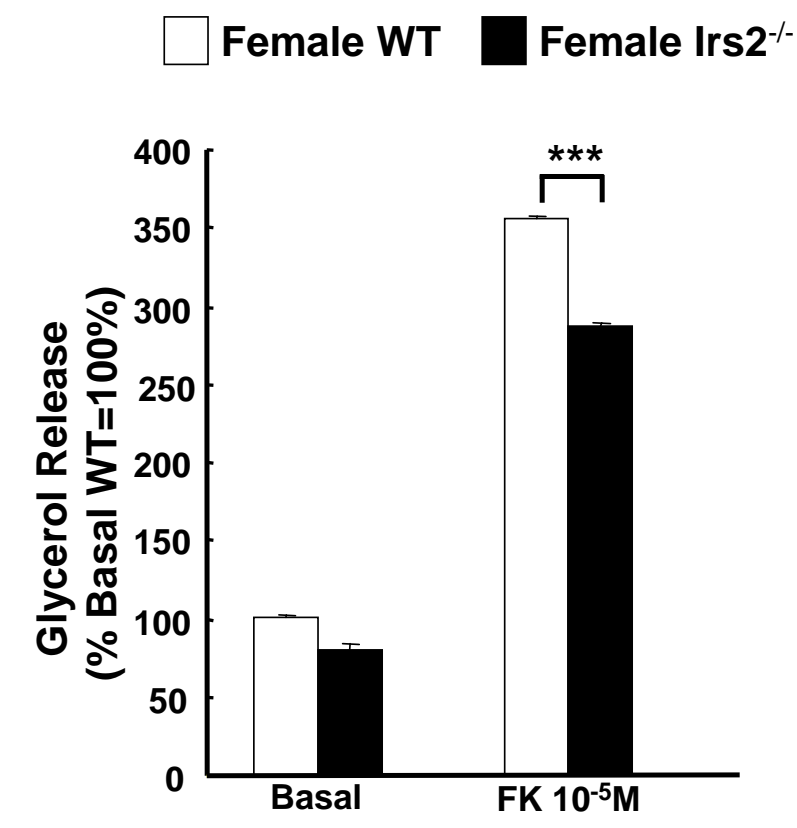

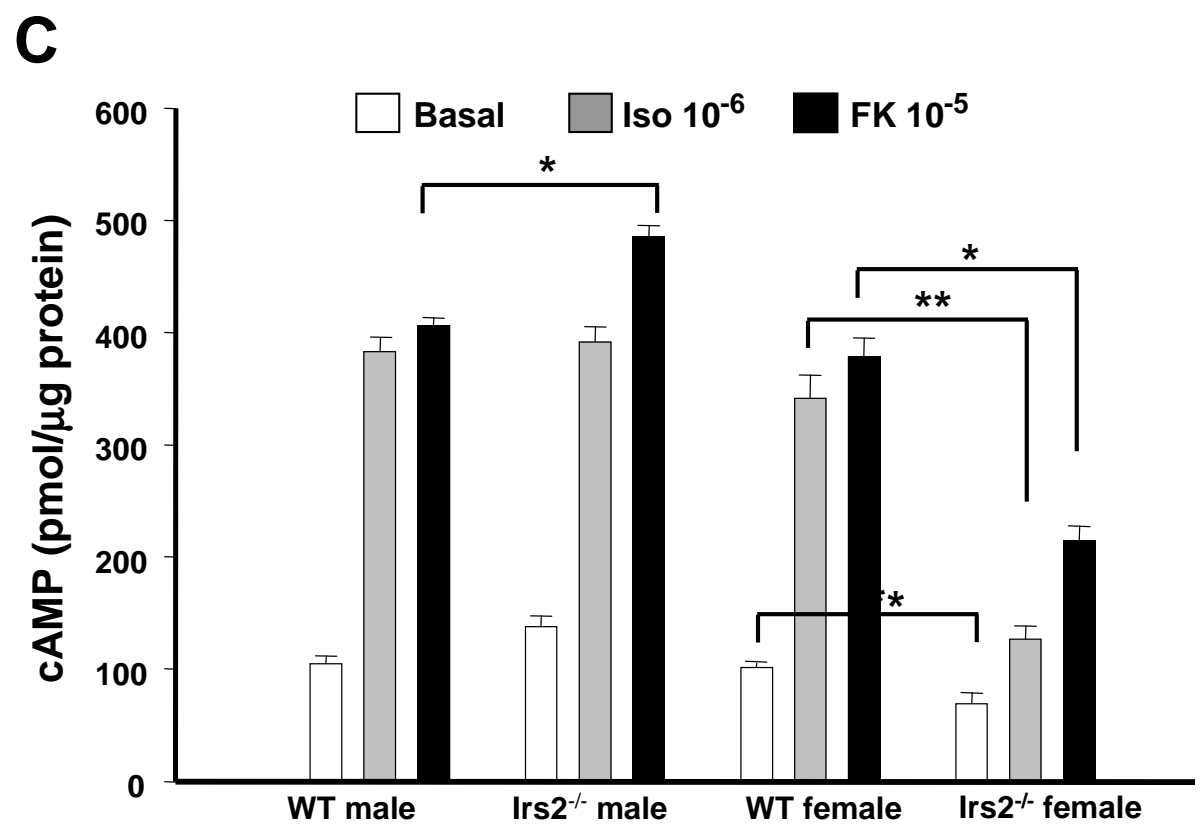


Garcia-Barrado Figure 6

A
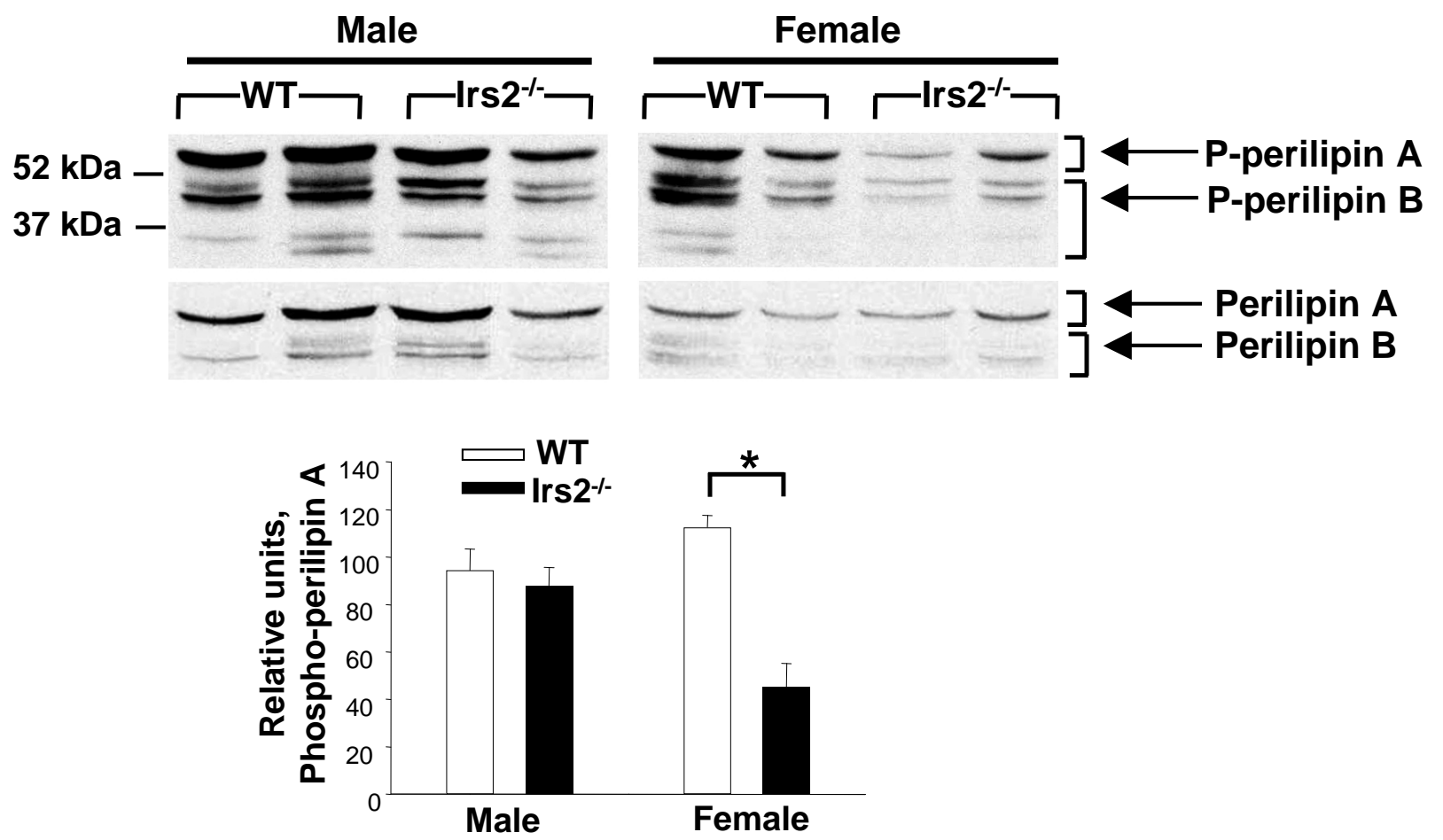

B

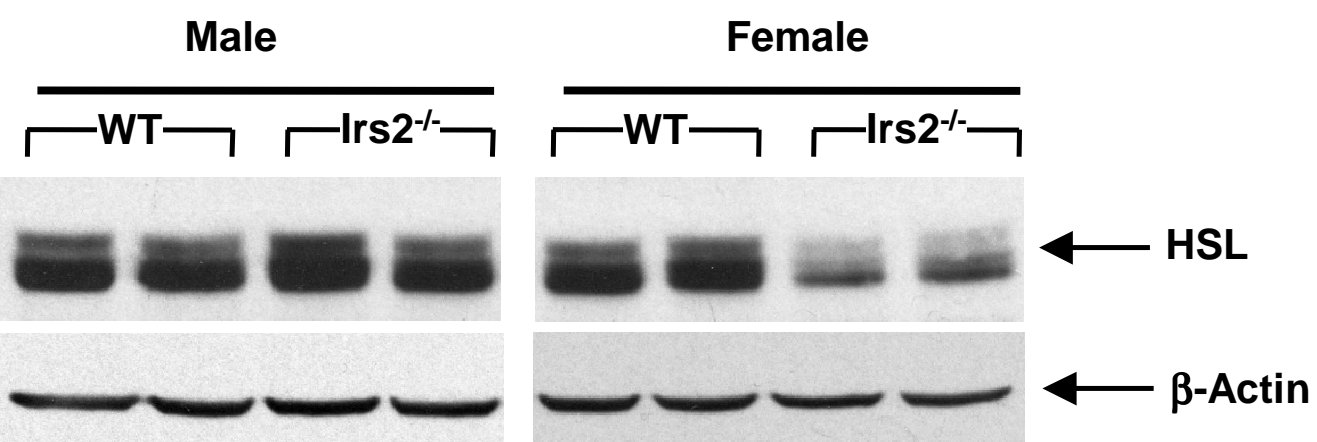


